Article

\title{
Feminists against Sexual Violence in War: The Question of Perpetrators and Victims Revisited
}

\author{
Maja Korac ${ }^{D}$ \\ Department of Social Sciences, Cass School of Education and Communities, University of East London, \\ London E16 2RD, UK; m.korac@uel.ac.uk
}

Received: 26 June 2018; Accepted: 26 September 2018; Published: 30 September 2018

\begin{abstract}
This article reflects upon feminist activism and analyses of sexual victimisation of women in war during the 1990s. It critically examines the reasons for the continuation of this type of violence against women, despite its recognition as a war crime; the recognition that marked one of the significant achievements of feminist activism during the last decade of the 20th century. The discussion points to the centrality of sexual violence in war for the system of gender based violence (GBV) against both women and men in war. It argues that a relational understanding of the gendered processes of victimisation in war is critical. This approach enables an acknowledgement that sexual violence in war and rape, as one of its expressions, is a violent political act that is highly gendered both in its causes and consequences, and, as such, it affects both women and men. This article provides an overall argument for the need of feminist scholarship and activism to engage with these differently situated experiences and practices of victimisation in war, to 'unmake' it.
\end{abstract}

Keywords: sexual violence against women; sexual violence against men; feminist anti-war activism; de-politicisation of male-on-male sexual violence

\section{Introduction}

I belong to the generation of women, feminist scholars, and activists, who were engaged in efforts to make sexual violence and rape of women in war visible and recognised as a war crime. ${ }^{1}$ At the time, I felt that all the work, both political and scholarly, compassion and empathy that characterised feminists' engagement during the 1990s had the ultimate positive impact on the situation of women in war zones. During the 1990s, there was an unprecedented focus on sexual violence in war, in scholarly, political, and the public domains. The Yugoslav wars of succession (1992-1995) and the Rwandan genocide (1994) brought the theme of sexual violence in war onto the international agenda. ${ }^{2}$ Although sexual violence in the context of armed conflict has a log history, as studies demonstrate (Brownmiller [1975] 2013), ${ }^{3}$ it entered the public, political, and very importantly, legal debate, only in the last decade

1 This is not to imply that my role in this process was in any way prominent. However, as a person, a woman, and a feminist scholar from war-torn country of Yugoslavia, I did my best to support the peace processes, challenge nationalistic politics and fight against the victimisation of women in war. In 1989, on the eve of the outbreak of armed violence in Yugoslavia, and throughout the 1990s, I was involved with local and international women's initiatives against nationalism and war in the region. As one of the founding members of the Women's Parliament (1989), as well as part of the Women in Black anti-war protests in Belgrade, London and Toronto, during the 1990s. The latter multi-sited activism was the expression of my transnational life at the time. As a feminist scholar, during the 1990s, I published 12 journal articles and books chapters, as well as a single authored book and a journal special issue about the Yugoslav wars of succession, tackling the issue of violence against women in these wars. I also participated in numerous academic conferences, public talks, and seminars around the world.

2 Skjelsbæk (2001) shows that there was a peak in the number of sexual violence in war related publications in the years 1993 and 1994.

3 This is not to argue that war is always accompanied by sexual violence. Some studies (Wood 2009) offer evidence that sexual violence is not part of every armed conflict. 
of the 20th century, instigated by activism and networking of local women during the first years of Yugoslav conflicts of succession. ${ }^{4}$ The first written accounts and analyses of the rape of women in Bosnia-Herzegovina were disseminated by local feminist groups in 1992-1993 (Batinic 2001, p. 14). ${ }^{5}$ They were appealing for material and financial support to set up provision of care for women survivors of sexual violence in war. They were also in search of ideas on how to apply political pressure on international institutions so that they would act (Batinic 2001).

However, despite this positive change, social and gender justice for the survivors of this type of violence were still without reach. It soon become apparent that it was the implementation of the newly won victory over the recognition of this specific type of sexual violence against women as the war crime that opened the space for further victimisation of women survivors of this type of violence (Henry 2014). They are further victimized in courtrooms, during court hearings that mute women's voices, because these spaces are structured around and underpinned by gendered meta-narratives or war (see for example Ross 2001). They are also further victimized in post-war settings of their communities and families, in which women survivors who testified have been stigmatised, rejected, harassed, and left with no prospect to rebuild their lives (see for example Nikolić-Ristanović 2000; MacKenzie 2010). All of this was followed by the further evidence that the change of the international law about war crimes does not have the deterring impact, as the brutal sexual victimization of women continues in the war zones of the 21st century.

While post-2000 feminist analyses have engaged critically with the work and knowledge production of the 1990s (e.g., Zarkov 2007), ${ }^{6}$ there is a lack of consideration of the political effects that the production and dissemination of this knowledge have contributed to. ${ }^{7}$ The acknowledgment of this role of local feminists that are involved in activist and conceptual work supporting women survivors of sexual violence in the wars of Yugoslav succession is, thus, the entry point to my discussion in this article, in which I reflect upon their engagement, during the 1990s. ${ }^{8}$ This provides a context for the discussion on the gendered question of perpetrators and victims/survivors that follows. I discuss the need to deconstruct further the essentialist notions of women as victims and men as perpetrators of violence in war. In doing so, I argue for the development of nuanced conceptualisations of men (and women) as both victims and perpetrators. This would allow for a comprehensive understanding of the power systems that operate by constructing essentialist notions of gender identities as 'natural' and fuel violence constructed as inevitable part of human experience. This discussion is followed by a critical analysis of sexual violence in war and its victims. I point to the evidence and growing literature on men as victims of a range of brutal, sexual violations of their bodies in war. I argue that the invisibility of this type of victimisation of men is the consequence of the depoliticiation of these otherwise highly political violent acts, because of their centrality to hegemonic formulations of masculinity that are embedded in the dominant notions of nationhood and statehood. The concluding section offers an overall argument for the need of feminist scholarship and activism to engage more systematically with these differently situated experiences and practices of victimisation in war. ${ }^{9}$

4 For the history of Yugoslav feminism, see Benderly (1997); Papic (1995); Batinic (2001, pp. 4-11).

5 Thus, the work of local women on disseminating information about mass rape and sexual violence took place before the first international factfinding mission in Bosnia-Hercegovina, which started in January 1993, led by the Amnesty International.

6 Mostly done by (feminist) scholars who were not also activists during the wars of the 1990s.

7 Skjelsbæk (2010, pp. 15-17), for example, in explaining why 1990s were the turning point that brought about a new understanding of rape and sexual violence in war, does not acknowledge the role of the political and scholarly work of local women.

8 I consider this important, because it was the political, social, and cultural context of Yugoslavia, in conjunction with a strong influence of the first way feminism, that critically shaped their politics, activism, and scholarly work during the 1990s wars of succession. For more on this, see Korac (1998). For more on the difficulties of being engaged in this process, see Litricin and Mladjenovic (1997).

9 While some key contributors to the feminist literature have addressed sexual violence against men in their analysis (see, e.g., Alison 2007; Askin 1999, 2003; Buss 2009; Grey and Shepard 2012; Jones 1994, 2002, 2006; Oosterveld 2011; Touquet and Gorris 2016), I share Grey and Shepard's view that the issue of sexual violence against men is still peripheral in feminist analyses of war violence and sexual violence, in particular (Grey and Shepard 2012, p. 5). 


\section{Effects of the Politicisation of Sexual Violence against Women in War: The 1990s and Beyond}

The well-rounded local feminist activism and theoretical reflection of the 1990s, about sexual violence in war, mentioned here and discussed elsewhere Korac 2016, focused on the security of women. ${ }^{10}$ Their relentless collaboration-local, in war zones of the 1990s, and international, led to the recognition of rape as a war crime. ${ }^{11}$ Consequently, the International Criminal Tribunal for the former Yugoslavia (ICTY) and the International Criminal Tribunal for Rwanda (ICTR) are the first war crime tribunals to deliberate on rape as a war crime as part of the judicial process. Moreover, the International Criminal Tribunal for Rwanda (ICTR) declared the first verdict in an international court where rape was included as a part of genocide. ${ }^{12}$

This activism, embedded in feminist scholarly and political work, also signified the crucial moment for women internationally, as it marked the beginning of an unprecedented focus on the security and rights of women in war and resulted in the UN Resolution 1325, on women, peace, and security (WPS) passed in 2000. ${ }^{13}$ Both achievements demonstrate that women's activism, scholarly work, and direct participation in security dialogue have an impact. They, however, also became co-opted by the institutional systems, such as nation-states or the NATO that are all maintaining and enhancing the patriarchal, nationalist, and militarist power systems, all of which make patriarchy a 'sustainable' gender system of power (Enloe 2017).

Sexual violence against women during the Yugoslav wars of succession in the 1990s, for example, was also made visible and put at the centre of the local and international public debates by the local nationalistic governments, which highjacked and manipulated this feminist initiated and led debate for their own nationalistic political ends. They were using sexual victimisation of 'their' women to strengthen gendered narratives of 'their endangered nations' and their territories. Local feminist groups were vocal in expressing criticism of their local governments' political manipulation and further victimisation of women survivors of sexual war violence (Batinic 2001). In this sense, the visibility of sexual abuse of women in war, created by feminist activism of the 1990s, was used to foster gender-power systems that underpin the processes of militarisation and war violence. Likewise, the NATO 'reading' of the UN Resolution 1325 and its 'translation' into the effort to 'mainstream' the WPS throughout its structures and activities did not undermine or question the destructive 'complexities of gender regimes' that form the matrix of the entire 'war system' (Cohn 2008). ${ }^{14}$

To begin to undermine these destructive gender regimes, it is also necessary to focus on men, peace and security, the acts and processes of gendered victimisation they entail. Central to this is the role of sexual violence in war and how this specific type of violence sits within the system of GBV against both women and men that unfolds in wars. In this sense, a relational understanding of the gendered processes of victimisation in war is critical (Korac 2016). In doing so, it is crucial to acknowledge that the sexual violence and rape in war, as one of its expressions, is a violent political act that is highly gendered both in its causes and consequences, and, as such, it affects both women and men. The highly political aspect of this pattern of violence and its significance for the militarization and the militarized violence,

10 My discussion in this paper refers to the discourse and the militarisation process primarily in Serbia and to some extent in Croatia, and the spread of war violence in Croatia and Bosnia. I consider pan-Yugoslav feminist anti-war activism prompted by these processes and examine specifically feminist peace activism of groups such as Women in Black's (WIB) in Serbia.

11 This process of feminist engagement and analyses was not unified either politically or conceptually. Differences ranged from approaches to the question of the relation between feminism and nationalism, to conceptualisations of what constitutes rape in war as a war crime. While these differences were and still are important to feminisms and types of their anti-war activism, these variations are not the focus of my discussion, because all these struggles led to the recognition of rape as a war crime, despite the differences. For more on different feminist conceptualisations of sexual violence in war, see Benderly (1997) and Skjelsbæk (2001).

12 Press statement release AFR/94 L/2895 (Internet version, http:/ / www.un.org/News/Presshttps:/ /www.un.org/press / en/1998/19980902.afr94.html).

13 The passing of this Resolution can be largely credited to pressure applied by women in the international forum, i.e., the Women's International League for Peace and Freedom and the International Alert.

14 For more on this process of 'translation' and problems of the NATO gender mainstreaming see Cockburn (2011). 
may be best appreciated if we note that research shows that, contrary to the widespread belief that war related sexual violence is mostly perpetrated by unruly militias and rebel forces, it is the state-led armed forces that are more likely to commit this type of violent acts (Cohen et al. 2013, p. 4). Given the prominent role that sexual violence in war has in perpetuating violent conflict, it is paramount to move away from the hierarchisation of women's and men's victimhood and engage in a relational understanding of the victimisation of both women and men by this type of violent acts. Such an approach holds a potential to begin to undermine the power systems that engender these varied types of victimisation of both women and men by gradually, but, ultimately, reshaping the homogeneous and essentialist notions of masculinity and femininity. This, in turn, can facilitate alternative ways of conceptualising and understanding varied processes of gender identity negotiations and formations, as well as how these processes unfold in (specific) war and historic situations, and how they are linked to the gender power relations that underpin them. I argue, that such a relational understanding of the gendered processes of victimisation of women and men in war has the potential to affect a positive social change and help with the long-drawn process of achieving gender-just and sustainable, peaceful social relations.

\section{Perpetrators and Victims: The Question of Male-Female Dichotomy}

Although much of the feminist activism and scholarship of the 1990s focused on the processes of victimisation of women in war, studies of gender aspects of conflict have been pointing out the diverse roles of women in waging war and building peace. ${ }^{15}$ Feminists have been documenting how women are not simply victims, but also agents, which are actively involved in violent actions, for example, as part of the military engagements, in Rwanda (Lentin 1997) or Sri Lanka (De Mal 2003). More recently, there is a growing body of feminist writings about women who sexually abuse men (e.g., Gentry 2009; MacKenzie 2009; Sjoberg and Gentry 2007; Sjoberg 2016). Women are also active in promoting peace, such as in Afghanistan (Collett 1998), Northern Ireland, Israel/Palestine, Bosnia-Herzegovina (Cockburn 1998), or Sri Lanka, and the successor states of Yugoslavia (Giles et al. 2003), as well in many other parts of the world (Cockburn 2012). In this sense, the introduction of gender into the conflict discourse has been important in deconstructing, to some extent, essentialist notions of women as victims, 'natural born nurturers' and of men as warriors and 'natural born rapists and killers'.

Local feminist scholars and activists during the Yugoslav wars of succession, for example, acknowledged how men are victimised by the imposition of conceptions of masculinity as warrior-like (Korac 1993, 1994; Papic 1994), and pointed out that the concept of 'militant masculinity' (Papic 1994, p. 14) in the region had been re-created to invoke the traditional-patriarchal masculine identity, ${ }^{16}$ to mirror that of a 'real warrior' who is capable of fighting 'sacred' ethno-national wars. Furthermore, some of the feminist anti-war campaigns, such as Women in Black's (WIB), were centred on lobbying activities for the rights of men evading conscription, including their rights to asylum within the European Union (EU) (Zajovic 1994). Such activism was part of feminists' confrontation with the process of militarisation of the society and their recognition that not all men identify with the 'warrior like' notion of masculinity.

It is estimated that there were hundreds of thousands of young men who fled Serbia and other Yugoslav successor states to avoid conscription and to seek sanctuary in the EU (Aleksov 1994). That is how many local men confronted this type of victimisation although it was never publicly or politically, locally or internationally, recognised as such. Instead, it was framed as an illegal act, both within the local political context, as well as in the international one. Men fleeing conscription during the Yugoslav wars of succession found themselves with no rights to international protection, although as

15 Some of these studies were published in the late 1990s, thus, during the decade characterised by an outstanding focus on victimisation of women in war.

16 For discussion on traditional/patriarchal masculine identity in the Balkans, see Denich (1974). 
deserters they faced up to 10 years in prison if deported, according to the law of the time (Aleksov 1994). Hence, not only were the local nationalistic governments abusing the rights of men to life, eager to boost their military forces that are destined to fight and kill. The governments of the EU states, involved at the time in what they considered were a series of active, constructive, humanitarian oriented interventions to prevent and stop wars, also viewed it as the right of sovereign states. Even of ones that they deemed 'failing' or 'extremist', to imprison men who refused to join the military, kill, and get killed. Consequently, these men were not seen as deserving international protection, as stipulated under the Geneva Refugee Convention in cases in which states are persecuting their own citizens and abusing their human rights. Instead, they were left in a limbo, without any support, relying on their individual resourcefulness and personal networks. ${ }^{17}$

The only support these courageous men received was from some local, feminist, anti-war, and anti-militarists groups, such as the WIB. Their recognition that the imposed notion of violent masculinity poses threat to men who oppose it had to some extent also contributed to the mobilisation of women around anti-war initiatives, during the early years of war. In explaining the reasons for women making up the majority in the early peace initiatives in Belgrade and Serbia, Mladjenovic (2003, p. 41) points out that one of the explanations for this is that the gender position of women made it safer for them to act against the Milosevic regime. ${ }^{18}$ Men were under threat of forced mobilisation, thus, had to keep a low public profile in anti-war protests.

Looking back at this type of feminist critique of the processes of enforcement of the notions of militant, violence-oriented masculinity of the 1990s, I realise how this engagement was critically linked to our concerns about the parallel process that lead to the imposition of a complementary notion of femininity, and, consequently, focused on their harmful consequences for women. This was not surprising, because the local feminists were aware that these two complementary notions of femininity and masculinity, as Enloe (1993) has pointed out long ago, underpin the gendered workings of power that are commonly transformed into violence against women. We were aware that 'our men' have always been boosted by the nation-states to take up arms to 'protect our women', constructed by ethno-national discourse as symbols of 'our culture', 'territory', and 'nation' (Walby 1992). Not surprisingly, therefore, local feminists were pointing out that women came to be seen as a means of renewing the nation. Hence, they became crucial for 'national security', and their bodies became defined by the government's military strategies (Papic 1995). Thus, women's reproductive rights were under threat in the wake of the violent breakup of Yugoslavia (Einhorn 1993; Kesic 1995), and their bodies soon turned into battlefields after the wars broke out. This primarily women centred approach to security of anti-war feminist activists and scholars of the 1990s, missed to acknowledge fully that men are, indeed, also central for 'national security'. Their bodies belong to the national military, and, hence, their right to life transforms into their obligation to sacrifice it for the nation. In this sense, both female and male bodies as well as women and men embodied in them are essentialised, albeit in different, but complementary ways. Militarisation and wars produce militarised, masculinised bodies, built to protect, defend, fight (Pile 2011 in Miles), and kill or be killed. In this sense, there is a clear link between war conditions and biopower, as pointed out by Agamben (1998, p. 3) and Foucault (1978, p. 137), because the violation of human body is a potent tool of nation-states and their militaries in determining questions of life and survival. Hence, the varied types of violation of women and men, and their different but complementary symbolic meanings are expressions of how the biological

17 Nermin's account, who is one of the Bosniak men who decided to flee Bosnia and the army and who I interviewed in Rome, in 2000, provides a glimpse of their situation: "The only thing I could afford was a trip to Italy. I came to Ancona in March 1995. I'd paid to be smuggled on a ship, I felt like a criminal. The only contact I'd had was a young woman from Bosnia-Herzegovina who was here in Rome. I didn't even call her, I just came." (Korac 2009, p. 50).

18 Slobodan Milosevic, the than President of so-called Rump Yugoslavia, after the unilateral succession of Slovenia and Croatia from the Federation of the Republics of Yugoslavia. 
features of female and male bodies are 'projected into a political strategy of a general strategy of power' (Foucault 2009, p. 1).

These related processes of victimisation of both women and men in war, emanating from the patriarchal nation-state systems of power, remained obscured and unacknowledged by most of the feminist anti-war activists and scholars, in the 1990s. Due to the proliferation of war violence at the time, the political struggle against war and work with victimised women led feminist activists to focus almost exclusively on women victims of war. The fact that women played hardly any active role as combatants in Yugoslav wars of succession, intensified their status as victims and men as perpetrators. ${ }^{19}$ This meant that a range of important questions about the causes and consequences of gendered violence and victimisation in Yugoslav wars of succession, for the most part, had not been considered. More generally, it can be argued that questions about gender-power systems that are linked to victimisation of both women and men in war have not gained prominence among feminists internationally. In this sense, Jones (1994) made an important point when he argued that men have been the 'absent subjects' in feminist analyses of gender and wars, the assertation based on his evaluation of gender-specific and gender-selective violence in the Yugoslav wars of succession. This has prevented the development of nuanced conceptualisations of men as both victims and perpetrators.

The construction of men as 'protectors', and as 'heroic' at that, has been one of the central pillars of the oppressive gender power systems inherent in the patriarchal nation-state structures, as well as the socio-economic and political systems that underpin them. Barry (2011) points out that it is this notion and systems of power that create them that must be 'unmade'. The first step in doing so, is to consider how it is felt to be moulded by socialisation, family, culture, and society as 'protector', 'heroic', and, consequently, 'superior'. ${ }^{20}$ When it comes to wars, the notion of the 'heroic protectors' ascribed to men as part of their responsibilities of citizenship, translates into the obligation to kill and the expectation to sacrifice their own lives. The latter points to the 'expandability' (Barry 2011, loc 329 , Kindle version) of men's lives in exchange of which they are socialised as 'superior' to others, notably - women whom they are required to protect. This false notion of superiority is what men gain in exchange for their commitment to keep up with expectations and requirements of manhood (ibid.). Barry's analysis of these processes of socio-cultural and gender identity 'translations' and how fundamentally that affects men's lives is a reminder that the perpetrators are indeed also victims of their position constructed as 'superior', within the gender systems of power (ibid.). She also points out how 'the making of soldiers' is 'the dehumanisation of men' (Barry 2011, loc 178; Kindle version). This kind of approach and conceptualisation is vital, not because the perpetrators should be excused and rendered not responsible for any atrocities that they commit. Rather, this kind of acknowledgement is key to taking on board the processes of victimisation that come with the 'heroic protector' role and related gender aspects of it. Critically, this type of conceptualisation enables understanding of what it takes to 'survive' or 'deviate' from the prescribed 'superiority' role. Barry (2011) pointedly argues that men 'disconnect' and 'suppress their humanity' to be able to cope with the burden of being made 'expandable' by their states, as well with the fear of having to kill and of being killed, when it comes to war. ${ }^{21}$ Indeed, this is necessary, because our societies and states impose powerful negative sanctions on men who refuse violent masculinity that is associated with the military, militarisation, and war, such as making it illegal, as pointed out earlier.

The power of the imposition of a variety of negative social sanctions on men who 'deviate' and how they can torment and victimise those who are deeply troubled by the implications of living up to their humane, non-violent values for their socially prescribed manhood is best demonstrated by the fate of Miroslav Milenković who killed himself after being drafted as a reservist into the army during

19 Zarkov's research shows that women combatants in these wars were very few (Zarkov 2007, p. 229).

20 This consideration echoes the need of women to articulate and conceptualise their experiences of living with and through gendered constructions of themselves as 'in need of protection', 'weak', 'emotional', hence, 'inferior'.

21 Human history demonstrates that when it comes to the matters of war, the question is 'when', rather than 'if'. 
Yugoslav succession wars. This construction worker, born in 1951, found himself standing between two groups of reservists on a square of the small town of Šid, to which the reservists were taken before being sent to 'the front'. On the one side were men who refused to take up weapons and thus faced social stigma and incarceration. On the other side were men who had chosen to take up arms and join the war in Croatia in which they were expected to kill others and possibly also be killed. Standing between two groups, he shot himself (Korac 1996).

I am not the only (local) feminist activists and scholar who has written about Miroslav Milenković as a victim of the wars, pointing out that men were victimised too. However, their victimisation, because of their gender, has never been approached as relational, and, thus, central to our analyses of gender based violence against women in war. The processes of diverse types of victimisation of women, including their sexual victimisation, are an integral part of the war violence that targets both women and men. To grasp the logic of violence in war and to tackle its causes, it is paramount to understand the gendered patterns of victimisation of both women and men. I see this relational approach now, as a critical prerequisite to start the process of 'unmaking' war if the goal is to affect a social change conducive to socio-economic and political relations that ensure human security. To do this, it is critical to engage with and to support the process of 'remaking' power systems and conditions that are constructing men as 'superior' by making them 'dispensable' (Barry 2011). The need to approach war related GBV as relational processes of victimization of both women and men, if we aim to 'unmake' war, is even more apparent when the sexual violence in war, is looked through a relational gender lens.

\section{Men as Victims of Sexual Violence in War: Gendered Meanings and Political Effects}

There has been a growing body of research in the past decade or so, on how men are victimised by sexual violence in war (e.g., Carpenter 2006; Misra 2015; Russell 2007). These scholarly discussions and debates have been mostly taking place within the boundaries of this specific niche of scholarly interest. Their insight and data are rarely considered in the mainstream social sciences, or, indeed, in the political or public domains. This still prevailing invisibility of the fact that men are victimised by varied and often gruesomely brutal acts of sexual violence in war is indicative of the stigma attached to this type of violation of man's body and self, of his manhood. ${ }^{22}$ The stigma is so deeply ingrained in the matrix of gender systems that form our outlook on the world, ranging from gender identities to socio-political relations that are structured by gender power systems, that even research that provides evidence on this type of victimisation of men or the voices of sexually victimised men themselves, are surrounded by disbelief. Therefore, it is not surprising, as Dolan (2011) and Watson (2014) reveal, that people working for organisations that provide support for war victims are often so shocked by the testimonies of sexually abused men that they refuse to believe it. Moreover, those NGOs and INGOs that support victims of sexual violence in war and have the knowledge of this type of victimisation of men often operate in societies and states that consider this type of violence against men a taboo (Misra 2015 , p. 201). Hence, their non-engagement with the sexually victimised men, although they are aware of their existence and suffering, is justified as 'strategic thinking' (ibid.).

Although men who fought wars of Yugoslav succession or lived through them as civilians were victimised by sexual violence during the conflicts, as well as were women, engagement with a relational, gendered investigation of male experiences of this type of victimisation was absent from our analyses and activism of the 1990s. Male-on-male sexual violence was employed systematically as a means of inflicting the utmost humiliation upon 'the enemy', and as a means of 'boosting morale' and instilling 'manliness' in the defenders of 'our' ethno-national collectives and territories. In this sense, sexual violence in war is a potent tool of war, because its processes and their enactment are not only profoundly violating human bodies. They are also communicating powerful symbolic messages that

22 Misra's study on sexual violence against men in war, provides a vivid insight into the brutality of this type of violence against men (Misra 2015, p. 124). 
are directed at warring parties, their communities and states, by harming the deeply seated individual sense of gender self and identity of the victimised. In doing so, acts of sexual violence in war, both against women and men, are manipulating the dominant socio-cultural notions of femininity and masculinity for spreading fear and for furthering war violence. In this sense, both male-on-male and male-on-female sexual violence is deployed or tolerated in armed conflict, because it has a 'collective meaning' (Seifert 1994, p. 36) connotating emasculation of the enemy's nation and/or boosting the hegemony of violent masculinity. The same process also safeguards the importance of the dominant notion of manhood and masculinity, by threatening the men who 'deviate'. Testimonies of perpetrators who were forced to rape women in Bosnian war disclose that they were ridiculed as not 'real men' and 'true' representatives of their nation, and threatened to be killed if they refuse to do it (Stiglmayer 1994, pp. 147-62). Kressel (2002, p. 17) study confirms that this was the case and that many men who refused orders to rape civilian women or men were often killed by their fellow soldiers. Moreover, the centrality of the dominant notion of manhood and masculinity for nation-states and how their power-systems are threatened by male-on-male violence is also evident from still prevailing criminalisation of sexually abused and victimised men, who become decoded as homosexual and encoded as criminal, by the homophobic laws of their nation-states (Misra 2015, pp. 154-57).

Evidence of male-on-male sexual violence in Yugoslav wars of succession, which were committed mostly in detention, has been available since 1994, published in the United Nations Commission of Experts' Final Report. ${ }^{23}$ Despite this evidence of men being deliberate targets of rape and other types of sexualised war violence committed by all warring parties in detention camps, ${ }^{24}$ this type of victimisation of men has not been acknowledged either by the media, anti-war activists, or, as already mentioned, in the feminist scholarly research and activism of the 1990s. One of the rare publications from the 1990s, referring to this kind of violence against men, was Jones (1994) who pointed out that because men have been the majority of concentration camp victims and as sexual violence is not uncommon in all-male settings, a more nuanced approach to an understanding of how the gender dimension works in the war-zone is needed (Jones 1994, p. 126).

Research available post-2000, has begun to demonstrate the scope of sexual violence against men in conflict in general, not only in the wars of Yugoslav succession. Peel (2004) has identified three main patterns of this type of violence experienced by men in conflict related settings. These are: sexual assault as part of the general interrogation process; sexual violence as an intimidation and humiliation strategy to brake enemy's political conviction and/or identity; and, rape of prisoners by soldiers or forced rape between the captives as a form of vengeance. The latter type of sexual victimisation of men was particularly widespread during the war in Bosnia, as indicated by the UN report of 1994. Mudrovcic (2001, p. 64) and Sivakumaran (2010, p. 263) studies reveal the scale of this type of victimisation of men in a greater detail; in the Serb-led concentration camp in the Sarajevo canton, for example, 80 per cent of 5000 men held there were raped, either by their captors or forced to rape each other. While studies indicate that sexual violence against men in war does not occur in every conflict, they also demonstrate that an overwhelming majority of male combatants have engaged in man-on-man sexual violence as an integral part of the combat (Misra 2015, p. 223). In the Liberian conflict, for example, of 1666 combatants who were surveyed, 32.6 per cent were sexually violated and victimised (Johnson et al. 2008; Sivakumaran 2010, p. 263). In Eastern Congo, in yet another example, which was in 2009 termed the 'the rape capital of the world' or 'the most dangerous place on earth to be a woman' by Margot Wallstrom, the UN's special representative on sexual violence in conflict (Autesserre 2012, p. 204), men are also experiencing conflict related sexual violence, as Storr (2011,

23 The United Nations Commission of Experts' Final Report, Annex IX: C; 1994, December 28. http: / /www.phdn.org/archives/ www.ess.uwe.ac.uk/comexpert/ANX/IX.htm\#r21.

24 As approximately $60 \%$ of some 150 detention camps in Bosnia and Croatia were Serb run, in terms of the scale of victimisation, Bosnian Muslim and Croat men were more often victims of rape than Serbian men. All men in these wars were, however, deliberate targets of rape and other brutal forms of sexualised war violence. 
p. 7) points out. In the past decade or so, sexual violence against men (and boys) has been reported in 25 armed conflicts (Russell 2007, p. 22). These violations include rape, sexual torture, mutilation of the genitals, sexual enslavement, forced incest, and forced rape (Russell 2007).

As much as the sexual violation of women in Yugoslav wars of succession was acknowledged as prominently political, by feminist activists and scholars, as well as by the local and international political elites who were manipulating the victimised women and their supporters, the sexual victimisation of men was actively de-politicized. Research shows, for example, that the media coverage of sexually abused men was almost non-existent in the local media, and internationally not reported at all (Zarkov 2001, pp. 71-73). Although some may find this difficult to believe or explain, particularly in the light of the fact that the 1990s were characterised by the focus on sexual violence in war, as mentioned at the beginning of this article, this is not surprising if one takes into consideration the social and political connotations of this kind of sexual violence in war. Men are subjected to rape and sexual violence as a way of proving that they do not belong to the category of men in whose image nationhood and statehood is significantly constituted. As such, this type of victimisation is profoundly humiliating for the victimised men, their communities, and nation states. The de-politicisation, by both the local governments as well as by the international institutions, of male-on-male rape and other forms of sexual violence against men are centrally linked to hegemonic formulations of masculinity that inform dominant notions of nationhood and statehood. That is why local national papers during wars of Yugoslav succession, for example, avoided stating the ethnicity of sexually abused men, if they were 'their' men (Zarkov 2001, pp. 74-75). At the level of the international institutional system, the de-politicization manifests itself as non-recognition of sexual violence against men-as an atrocity and as a human right violation, Stemple $(2009$, p. 612) study points out, even when INGOs have inside knowledge of this type of violence occurring in wars.

\section{Concluding Remarks}

Reasons for which sexual victimisation of men in war have been actively de-politicised and rendered invisible are deeply political in nature. Making it visible and conceptualised as an integral part of the processes involved in instigating and committing seual violence that affects both women and men is critical for undermining its patriarchal logic of power and for 'unmaking' war. Thus, my discussion in this article is not a call for a 'gender neutral' approach or a 'holistic' response to these types of victimisation of women and men in war, as Misra (2015, pp. 196, 205) suggests. Nor it is an argument for undermining decades of many major feminist struggles against violence inflicted on women in both war and peace. Rather, it is a call for a more radical challenge to the patriarchal state systems of gender-power relations that discriminate against both women and men. This carries a potential of undermining its 'sustainability' by opening a space for alternative, inclusive ways of conceptualising and understanding gender differences.

Theoretical analyses of masculinities (e.g., Connell 1995; Connell and Messerschmidt 2005) have helped to reveal the full, nuanced picture of how hegemonic masculinity is inseparable from power in its many forms: physical power, ${ }^{25}$ including power to attack and protect, sexual power, economic power, political power, intellectual power, and moral power. Depending on a historic and cultural context, some of these aspects of power become more prominent in shaping the hegemonic notion of 'normal/accepted' men. The invisibility of sexual atrocities against men committed by men in the Yugoslav wars of succession and other armed conflicts demonstrate that the intersection of sexuality, masculinity, and ethnicity/nation, is one of the central power dynamics that shape dominant notions of statehood and its power systems, from local to international. If the patriarchal notions of nationhood and statehood are to prevail, the notions of men as protectors, victors, and superior, must remain

25 Cockburn (2009, p. 270) points out how men must be visible in their physicality if patriarchal gender relations are to be seen clearly 'working' both at work and in the domestic sphere. 
unchallenged. The visibility of raped men within a patriarchal context would emasculate not only the victims themselves, but also the notion of the nation and the state by eroding the very gender-power system upon which it is built. ${ }^{26}$

From this perspective, to acknowledge the diversity of men's experiences of war, including sexual violence against them, and to approach them as an integral part of the process that cause these types of violence against both women and men, is to conceptualise gendered victimisation as relational and to demand gender integrated interventions at multiple levels: state, community, and individual. ${ }^{27}$ This should be considered as a way of undermining a male-centred conceptualisation of a 'default humanity' that shapes patriarchal power and masculinised gender hierarchies, which impose considerable costs upon men and boys, not only women and girls, as Connell (2008) notes. A starting point to this challenge to the existing, totalising gender-power relations that continue to perpetuate gender inequalities, while victimising both women and men, are lives on the margin, beyond masculine elite power, of both women and men. While the quest for gender equality and an end to gender-based oppression and violence will continue to require specific, separate struggles of women and men for their rights and wellbeing, the struggle to put an end to the sexual violence in war, and its powerful victimisation mechanisms is one that can be successful only if done together, with men. As the old African saying reminds us: 'If you want to go quickly, go alone; if you want to go far, go together.'

Funding: This research received no external funding

Conflicts of Interest: The author declares no conflict of interest.

\section{References}

Agamben, Giorgio. 1998. Homo Sacer: Sovereign Power and Bare Life. Stanford: Stanford University Press.

Aleksov, Bojan, ed. 1994. Deserters from the War in Former Yugoslavia. Belgrade: Women in Black.

Alison, Miranda. 2007. Wartime Sexual Violence: Women's Human Rights and Questions of Masculinity. Review of International Studies 33: 75-90. [CrossRef]

Askin, Kelly D. 1999. Sexual Violence in Decisions and Indictments of the Yugoslav and Rwandan Tribunals: Current Status. American Journal of International Law 93: 97-123. [CrossRef]

Autesserre, Séverine. 2012. Dangerous Tales: Dominant Narratives on the Congo and their Unintended Consequences. African Affairs 111: 202-22. [CrossRef]

Barry, Kathleen. 2011. Unmaking War, Remaking Men: How Empathy Can Reshape Our Politics, Our Soldiers and Ourselves. Phoenix: Phoenix Rising Press of Santa Rosa.

Batinic, Jelena. 2001. Feminism, Nationalism, and War: The 'Yugoslav Case' in Feminist Texts. Journal of International Women's Studies 3: 1-23.

Benderly, Jill. 1997. Rape, Feminism, and Nationalism in the War in Yugoslav Successor States. In Feminist Nationalism. Edited by Lois A. West. New York: Routledge, pp. 59-74.

Brownmiller, Susan. 2013. Against Our Will: Men, Women and Rape. New York: Open Road, Integrated Media. First published 1975.

Buss, Doris. 2009. Rethinking ‘Rape as a Weapon of War'. Feminist Legal Studies 17: 45-63. [CrossRef]

Carpenter, R. Charli. 2006. Recognizing Gender-Based Violence against Civilian Men and Boys in Conflict Situations. Security Dialogue 37: 83-103. [CrossRef]

Cockburn, Cynthia. 1998. The Space between Us: Negotiating Gender and National Identities in Conflict. London: Zed Books.

Cockburn, Cynthia. 2009. On the Machinery of Dominance: Women, Men, and Technical Know-how. Women's Studies Quarterly 37: 269-73. [CrossRef]

26 This also explains increased insecurity of LGBT populations in conflict and post-conflict zones, as they are perceived as 'unwanted others'.

27 As opposed to the so-called gender mainstreaming that translates into adding women to otherwise unchanged patriarchal gender power systems and structures, by 'allowing' women to take on roles traditionally perceived as men's. 
Cockburn, Cynthia. 2011. Snagged on the Contradiction: NATO UNSC Resolution 1325, and Feminist Responses. Unpublished manuscript. Available online: http:/ / www.cynthiacockburn.org/BlogNATO1325. pdf (accessed on 17 February 2012).

Cockburn, Cynthia. 2012. antiMILITARISM: Plotical and Gender Dynamics of Peace Movements. New York and Basingstoke: Palgrave Macmillan.

Cohen, Dara Key, Amelia Hoover Green, and Elisabeth Jean Wood. 2013. Wartime Sexual Violence, Misconceptions, Implications, and Ways Forward. Special Report 323. Washington: United States Institute of Peace.

Cohn, Carol. 2008. Mainstreaming Gender in UN Security Policy: A Path to Political Transformation. In Analysing and Transforming Global Governance: Feminist Perspectives. Edited by Shirin M. Rai and Georgina Waylen. Cambridge: Cambridge University Press.

Collett, Pamela. 1998. Afghan women in the peace process. In The Women and War Reader. Edited by Lois Ann Lorentzen and Jennifer Turpin. New York: New York University Press, pp. 323-28.

Connell, Robert W. 1995. Masculinities. Cambridge: Polity Press.

Connell, Robert W. 2008. Preface. In Rethinking the Men Question: Sex, Gender, and Violence in International Relations. Edited by Marysia Zalewski and Jane Parpart. London: Zed Books.

Connell, Robert W., and James W. Messerschmidt. 2005. Hegemonic Masculinity: Rethinking the Concept. Gender and Society 19: 829-59. [CrossRef]

De Mal, Neloufer. 2003. Agent or victim? The Sri Lankan woman militant in the interregnum. In Feminists under Fire: Exchanges across War Zones. Edited by Wenona Giles, Malathi de Alwis, Edith Klein, Neluka Silva, Maja Korac, Djurdja Knezevic and Zarana Papic. Toronto: Between the Lines, pp. 55-74.

Denich, Betty. 1974. Sex and Power in the Balkans. In Women, Culture and Society. Edited by Michelle Zimbalist and Louise Lamphere. Stanford: Stanford University Press, pp. 243-62.

Dolan, Chris. 2011. Militarized, Religious and Neo-colonial: The Triple-bind Confronting Men in Contemporary Uganda. In Men and Development: Politicizing Masculinities. Edited by Andrea Cornwall, Jerker Edström and Alan Greig. London: Zed Books, pp. 126-38.

Einhorn, Barbara. 1993. Cinderella Goes to Market: Citizenship, Gender and Women's Movements in East and Central Europe. London: Verso.

Enloe, Cynthia. 1993. The Morning After: Sexual Politics at the End of the Cold War. Berkeley: University of California Press.

Enloe, Cynthia. 2017. The Big Push: Exposing and Challenging the Persistence of Patriarchy. Oxford: Myriad Editions.

Foucault, Michael. 1978. The History of Sexuality: An Introduction. New York: Random House, vol. 1.

Foucault, Michael. 2009. Security, Territory, Population. Lectures at the College De France, 1977-78. London: Pelgrave MacMillan.

Gentry, Caron E. 2009. Twisted Maternalism: From Peace to Violence. International Feminist Journal of Politics 11: 235-52. [CrossRef]

Giles, Wenona, Malathi de Alwis, Edith Klein, Neluka Silva, Maja Korac, Djurdja Knezevic, and Zarana Papic, eds. 2003. Feminists under Fire: Exchanges across War Zones. Toronto: Between the Lines, pp. 55-74.

Grey, Rosemary, and Laura J. Shepard. 2012. Stop Rape Now? Masculinity, Responsibility, and Conflict-related Sexual Violence. Men and Masculinities 16: 1-21.

Henry, Nicola. 2014. The Fixation on Wartime Rape: Feminist Critique and International Criminal Law. Social $\mathcal{E}$ Legal Studies 23: 93-111.

Johnson, Kirsten, Jana Asher, Stephanie Rosborough, Amisha Raja, Rajesh Panjabi, Charles Beadling, and Lynn Lawry. 2008. Association of Combatant Status and Sexual Violence with Health and Mental Health Outcomes in Postconflict Liberia. Journal of the American Medical Association 300: 676-90. [CrossRef] [PubMed] Jones, Adam. 1994. Gender and Ethnic Conflict in ex-Yugoslavia. Ethnic and Racial Studies 17: 114-34. [CrossRef] Jones, Adam. 2002. Gender and Genocide in Rwanda. Journal of Genocide Research 4: 65-94. [CrossRef]

Jones, Adam. 2006. Straight as a Rule: Heteronormativity, Gendercide, and the Noncombatant Male. Men $\mathcal{E}$ Masculinities 8: 451-69.

Kesic, Vesna. 1995. From Respect to Rape. Warreport 36: 36-38.

Korac, Maja. 1993. Serbian Nationalism: Nationalism of My Own People. Feminist Review 45: 108-113. [CrossRef]

Korac, Maja. 1994. Representation of Mass Rape in Ethnic Conflicts in what was Yugoslavia. Sociologija 36: 369-527. 
Korac, Maja. 1996. Ethnic Conflict, Rape and Feminism: The Case of Yugoslavia. In Research on Russia and Eastern Europe: Women in Post-communism. Edited by Metta Spencer and Barbara Wejnert. Greenwich and London: JAI Press Inc., vol. 2, pp. 247-66.

Korac, Maja. 1998. Linking Arms: Women and War in Post-Yugoslav Sates. Women and Nonviolence Series, No. 6; Uppsala: Life \& Peace Institute.

Korac, Maja. 2009. Remaking Home: Experiences of Reconstructing Life, Place and Identity in Rome and Amsterdam. Oxford: Berghahn Books.

Korac, Maja. 2016. Is there a right time for gender just peace? Feminist anti-war organising revisited. Gender and Education 28: 431-44. [CrossRef]

Kressel, Neil J. 2002. Mass Hate: The Global Rise of Genocide and Terror. Boulder: Westview Press.

Lentin, Ronit, ed. 1997. Gender and Catastrophe. London: Zed Books.

Litricin, Vesna, and Lepa Mladjenovic. 1997. Belgrade Feminists: Separation, Guilt, and Identity Crisis. In Ana's Land: Sisterhood in Eastern Europe. Edited by Tanya Renne. Boulder: Westview Press, pp. 179-85.

MacKenzie, Megan. 2009. Securitization and Desecuritization: Female Soldiers and the Reconstruction of Women in Post-Conflict Sierra Leone. Security Studies 18: 241-61. [CrossRef]

MacKenzie, Megan. 2010. Securitizing Sex? International Feminist Journal of Politics 12: 202-21. [CrossRef]

Misra, Amalendu. 2015. The Landscape of Silence: Sexual Violence against Men in War. London: Hurst.

Mladjenovic, Lepa. 2003. Women in Black against War (Belgrade). In Feminists under Fire: Exchanges across War Zones. Edited by Wenona Mary Giles, Malathi de Alwis, Edith Klein, Neluka Silva, Maja Korac, Dubravka Knezevic and Zarana Papic. Toronto: Between the Lines, pp. 25-36.

Mudrovcic, Zeljka. 2001. Sexual and Gender-Based Violence in Post-Conflicts Regions: The Bosnia and Herzegovina Case. In The Impact of Armed Conflict on Women and Girls: A Consultative Meeting on Mainstreaming Gender in Areas of Conflict and Reconstruction. New York: UNFPA, pp. 60-76.

Nikolić-Ristanović, Vesna. 2000. Žrtve ratova u bivšoj Jugoslaviji: obim, struktura i obrasci viktimizacije. [Victims of War in the former Yugoslavia: Scope, Structure and Patterns of Victimisation]. Temida 2: 11-21.

Oosterveld, Valerie. 2011. The Gender Jurisprudence of the Special Court for Sierra Leone: Progress in the Revolutionary United Front Judgments. Cornell International Law Journal 44: 49-74.

Papic, Zarana. 1994. From State Socialism to State Nationalism: The Case of Serbia in Gender Perspective. Refuge 14: $10-15$.

Papic, Zarana. 1995. Women's Movement in Former Yugoslavia: 1970s and 1980s. In What Can We Do for Ourselves? East European Conference. Edited by Marina Blagojevic, Dasa Duhacek and Jasna Lukic. Belgrade: Centre for Women's Studies, Research and Communication, pp. 46-63.

Pile, Steve. 2011. Spatialities of Skin: The Chafing of Skin, Ego and Second Skins in T.E. Lawrence's Seven Pillars of Wisdom. Body E Society 17: 57-81.

Ross, Fiona Chiswell. 2001. Speech and Silence: Women's Testimony in the First Five Weeks of Public Hearings of the South African Truth and Reconciliation Commission. In Remaking a World: Violence, Social Suffering and Recovery. Edited by Veena Das, Arthur Kleinman and Margaret Lock. Berkeley: University of California Press, pp. 250-80.

Russell, Wynne. 2007. Sexual Violence against Men and Boys. Forced Migration Review 2: 22-23.

Seifert, Ruth. 1994. War and Rape: A Preliminary Analysis. In Mass Rape: The War against Women in Bosnia-Herzegovina. Edited by Alexandra Stiglmayer. Lincoln: University of Nebraska Press, pp. 54-72.

Sivakumaran, Sandesh. 2010. Lost in Translation: UN Responses to Sexual Violence against Men and Boys in Situations of Armed Conflict. International Review of the Red Cross 92: 259-77. [CrossRef]

Sjoberg, Laura. 2016. Women as Wartime Rapists: Beyond Sensation and Stereotyping. New York: New York University Press.

Sjoberg, Laura, and Caron Gentry. 2007. Mothers, Monsters, Whores: Women's Violence in Global Politics. New York: Zed Books.

Skjelsbæk, Inger. 2001. Sexual Violence and War: Mapping Out a Complex Relationship. European Journal of International Relations 7: 211-37. [CrossRef]

Stemple, Lara. 2009. Male Rape and Human Rights. Hastings Law Journal 60: 605.

Stiglmayer, Alexandra, ed. 1994. Mass Rape: The War against Women in Bosnia-Herzegovina. Lincoln: University of Nebraska Press. 
Storr, Will. 2011. The rape of men. The Guardian, July 17. Available online: http:/ /www.guardian.co.uk/society / 2011/jul/17/the-rape-of-men?INTCMP=SRCH (accessed on 15 November 2011).

Touquet, Heleen, and Ellen Gorris. 2016. Out of the shadows? The inclusion of men and boys in conceptualisations of wartime sexual violence. Reproductive Health Matters 24: 36-46. [CrossRef] [PubMed]

Walby, Sylvia. 1992. Woman and Nation. International Journal of Comparative Sociology 32: 81-100. [CrossRef]

Watson, Callum. 2014. Preventing and Responding to Sexual and Domestic Violence against Men: A Guidance Note for Security Sector Institutions. Geneva: Centre for the Democratic Control of Armed Forces (DCAF).

Wood, Elisabeth. 2009. Armed Groups and Sexual Violence: When Is Wartime Rape Rare? Politics E Society 37: 131-62.

Zajovic, Stasa, ed. 1994. Women for Peace: Anthology. Belgrade: Women in Black, pp. 1-188.

Zarkov, Dubravka. 2001. The Body of the Other Man: Sexual Violence and the Construction of Masculinity, Sexuality and Ethnicity in Croatian Media. In Victims, Perpetrators or Actors? Gender, Armed Conflict and Political Violence. Edited by Caroline O. N. Moser and Fiona C. Clark. London: Zed Books, pp. 69-82.

Zarkov, Dubravka. 2007. The Body of War: Media, Ethnicity, and Gender in the Break-up of Yugoslavia. Durham: Duke University Press.

Peel, Michael. 2004. Men as Perpetrators and Victims. In Rape as a Method of Torture. Edited by Michael Peel. London: Medical Foundation for the Care of Victims of Torture, pp. 61-69.

(c) 2018 by the author. Licensee MDPI, Basel, Switzerland. This article is an open access article distributed under the terms and conditions of the Creative Commons Attribution (CC BY) license (http://creativecommons.org/licenses/by/4.0/). 